\title{
An ATP-independent complex commits pre-mRNA to the mammalian spliceosome assembly pathway
}

\author{
Susan Michaud and Robin Reed \\ Department of Cellular and Molecular Physiology and Program in Cellular and Developmental Biology, Harvard Medical \\ School, Boston, Massachusetts 02115 USA
}

Previous studies have identified five distinct mammalian splicing complexes that assemble on pre-mRNA in vitro. Of these complexes, which include $H, E, A, B$, and $C$, only the $B$ and $C$ complexes have been isolated and shown directly to be functional intermediates in the splicing pathway. In this report we carried out a systematic analysis of the temporal and functional relationships among the $\mathrm{H}, \mathrm{E}, \mathrm{A}$, and $\mathrm{B}$ complexes. Using gel filtration to isolate each complex, we show that $H$ complex, which consists primarily of hnRNP proteins, assembles first in either the presence or absence of ATP. Subsequently, E complex, which contains stably bound U1 snRNP, is detected in reactions lacking ATP, whereas A complex, which contains stably bound U1 and U2 snRNPs, is detected in reactions containing ATP. We show that E complex can be chased into A and B complexes and that $A$ complex can be chased into $B$ complex. Both $E$ and $A$ complexes can also be chased into spliced products. In contrast, $H$ complex cannot be chased into $A$ or $B$ complexes or spliced products under the same conditions. We conclude that in addition to the two spliceosome complexes (B and $C$ ), two distinct pre-spliceosome complexes ( $E$ and $A$ ) are functional intermediates in the splicing pathway. Comparison of the efficiency of spliceosome assembly on different pre-mRNAs has revealed dramatic differences. We show that these differences are first apparent at the time of $E$ complex assembly. Thus, we conclude that E complex commits pre-mRNA to the splicing pathway and that this step is critical in determining the efficiency of mammalian spliceosome assembly.

[Key Words: ATP-independent complex; pre-mRNA; mammalian spliceosome assembly]

Received July 15, 1991; revised version accepted October 30, 1991.

Spliceosomes contain small nuclear ribonucleoproteins (snRNPs) U1, U2, U4, U5, and U6 (for reviews, see Krainer and Maniatis 1988; Steitz et al. 1988; Bindereif and Green 1990; Lamond et al. 1990; Mattaj 1990), as well as many non-snRNP factors (Kramer 1988; Vijayraghavan et al. 1989; Reed 1990; Kramer and Utans 1991). U1 snRNP base-pairs to the 5 '-splice site, and U2 snRNP base-pairs to the branchpoint sequence (Zhuang and Weiner 1986; Parker et al. 1987; Seraphin et al. 1988; Siliciano and Guthrie 1988; Wu and Manley 1989). In contrast, U4, U5, and U6 snRNPs do not appear to interact directly with the splice sites (Bindereif and Green 1987). Of the mammalian, non-snRNP splicing components that have been characterized, U2AF binds to the pyrimidine tract at the 3 '-splice site (Zamore and Green 1991) while the interaction sites of three other factors, SF2/ASF (Ge and Manley 1990; Krainer et al. 1990), SC35 (Fu and Maniatis 1990), and SF4 (Utans and Kramer 1990), are not known.

Spliceosomes appear to assemble in a stepwise manner in vitro, and the outlines of this assembly pathway have been derived from a large number of studies in both yeast and mammals (Frendewey and Keller 1985; Grabowski and Sharp 1986; Konarska and Sharp 1986, 1987; Pikielny et al. 1986; Bindereif and Green 1987; Cheng and Abelson 1987; Zillmann et al. 1987, 1988; Ruby and Abelson 1988; Seraphin and Rosbash 1989, 1991; Reed 1990). U1 and U2 snRNPs bind to pre-mRNA early in the reaction, followed by binding of U4, U5, and U6 snRNPs (for review, see Krainer and Maniatis 1988). These ordered snRNP/pre-mRNA interactions occur within discrete complexes that contain a number of non-snRNP components as well (Kramer 1988; Pruzan et al. 1990; Reed 1990; Kramer and Utans 1991). Both non-snRNP and snRNP components are likely to play key roles in splice site recognition and in establishing the pattern of splice site selection. Thus, in addition to determining the precise order of snRNP/pre-mRNA interactions, it is also important to identify and characterize the functional splicing complexes containing these snRNPs.

In yeast, the earliest detectable splicing complex assembles in the absence of ATP and contains UI snRNP (Ruby and Abelson 1988; Seraphin and Rosbash 1989, 1991). Significantly, functional studies have demonstrated that this complex commits pre-mRNA to the spliceosome assembly pathway /Seraphin and Rosbash 
1989|. In addition, U1 snRNP binding to pre-mRNA precedes, and is required for, stable binding of U2 snRNP (Ruby and Abelson 1988; Seraphin and Rosbash 1989). In contrast to yeast, there has been considerable confusion about the roles of U1 and U2 snRNPs in the initial steps of mammalian spliceosome assembly. This is due, in part, to discrepancies obtained from the use of different fractionation methods for characterizing splicing complexes.

In mammals, $\mathrm{U} 1$ snRNP appears to bind to pre-mRNA first when affinity chromatography or RNase protection/ immunoprecipitation are used as assays (Black et al. 1985; Bindereif and Green 1987). U1 snRNP binding occurs in the absence of ATP (Black et al. 1985). This observation is consistent with the finding that a discrete ATP-independent complex $(E)$, containing $U 1$ snRNP and other components, is the first specific complex detected by gel filtration (Reed 1990). However, an ATPdependent complex (A), which contains U2 snRNP, but not U1 snRNP, is the first specific complex detected by native gel electrophoresis, or by affinity chromatography in the presence of heparin (Grabowski and Sharp 1986; Konarska and Sharp 1986; 1987). U2 snRNP is also present in a complex reconstituted from partially purified fractions of nuclear extracts (Kramer 1988; Pruzan et al. 1990; Kramer and Utans 1991). This reconstituted complex, which appears to correspond to A complex, contains several known splicing factors (Kramer 1988; Kramer and Utans 1991) and can be chased into spliceosomes and splicing intermediates (Pruzan et al. 1990). By using other native gel fractionation conditions, both $\mathrm{U} 1$ and U2 snRNPs have been detected in A complex (Zillmann et al. 1987, 1988). Although studies with snRNPdepleted extracts revealed that U1 and U2 snRNPs can bind pre-mRNA independently of one another (Barabino et al. 1990|, Ul snRNP is required for A complex assembly (Zillmann et al. 1988; Barabino et al. 1990).

Together, these studies suggest that at least two distinct splicing complexes, $\mathrm{A}$ and $\mathrm{E}$, assemble at early times during the splicing reaction. However, because different fractionation methods were used to detect these complexes, the relationship between them has not been clearly established. In addition, neither complex has been isolated directly from splicing extracts and shown to be a functional intermediate in the pathway.

In this report we used a combination of gel filtration and affinity chromatography to isolate and characterize the $\mathrm{E}$ and A complexes. We show that the ATP-independent $\mathrm{E}$ complex commits pre-mRNA to the spliceosome assembly pathway and is a functional precursor to the ATP-dependent A complex. We also show that A complex is a functional precursor to $B$ complex. Both $A$ and E complexes can be chased into spliced products. Thus, the early steps in mammalian spliceosome assembly involve the stepwise assembly of two distinct pre-spliceosome complexes.

\section{Results}

In previous studies two mammalian spliceosome com- plexes-one containing unspliced pre-mRNA (B complex; Abmayr et al. 1988- and the other containing splicing intermediates (C complex; Reed et al. 1988), were isolated by gel filtration and chased into spliced products using in vitro complementation assays ( $\mathrm{Ab}$ mayr et al. 1988; Reed et al. 1988). These studies indicate that splicing complexes can be isolated by gel filtration in a functional form. We therefore used this approach to investigate the initial steps in spliceosome assembly. For the experiments described below, we employed several different gel-filtration columns for fractionation of splicing complexes. Although all of the columns were prepared similarly, we do observe variations in the precise fractions in which the same complex elutes (e.g., Fig. $1 \mathrm{~A}, \mathrm{~B}$, cf. position of $\mathrm{H}$ complex peak at $\left.\mathrm{O}^{\prime}\right)$. However, within a particular column profile, the relative positions of the peaks provided an initial indication of the identity of the complexes. This was then confirmed by determining the small nuclear RNA (snRNA) (see Fig. 3, below) and/or protein (M. Bennet, unpubl.) composition of affinity-purified complexes.

Splicing complexes were assembled on adenovirus major late (AdML) pre-mRNA by incubation in splicing extracts, either lacking (Fig. lA) or containing (Fig. 1B) ATP, and then fractionated by gel filtration. For comparison, similar samples were fractionated on native gels containing Tris-glycine buffer (Fig. 2; Konarska and Sharp 1987). For all reactions carried out in the absence of ATP, endogenous ATP was depleted from splicing extracts as described in Materials and methods. At the $0^{\prime}$ time point, in both the presence and absence of ATP, the vast majority of pre-mRNA elutes as a relatively homogeneous peak by gel filtration (Fig. $\left.1 \mathrm{~A}, \mathrm{~B} ; 0^{\prime}\right)$. This peak corresponds to $\mathrm{H}$ complex on native gels (Konarska and Sharp 1986; Fig. 2, lanes 1,5). Previous studies showed that $\mathrm{H}$ complex is not specific to splicing substrates as it assembles on RNAs lacking functional splice sites (Konarska and Sharp 1986; Reed 1990|. Recently, affinitypurified $\mathrm{H}$ complex was shown to consist almost exclusively of heterogenous nuclear ribonucleoprotein (hnRNP) proteins whether the complex is assembled in the presence or absence of ATP (D. Staknis et al. in prep.). The shoulder that elutes slightly faster than $\mathrm{H}$ complex (Fig. 1A,B; $0^{\prime}$ ) was not investigated further. However, we believe that it corresponds to lower levels of the peaks observed at the $2^{\prime}$ time point (Fig. 1A,B). This small amount of assembly may occur during the time taken to load the gel-filtration columns.

Only one complex is resolved on native gels for the remaining time points in the absence of ATP (Fig. 2, lanes 6-81. However, when the same reactions are fractionated by gel filtration, a peak that elutes prior to $\mathrm{H}$ complex is detected by the $2^{\prime}$ time point, continues to increase in amounts until the $15^{\prime}$ time point, and is only slightly greater by $25^{\prime}$ (Fig. 1A). We will refer to this peak as $E$ complex because data presented below indicate that it corresponds to the ATP-independent E complex detected previously on $\beta$-globin pre-mRNA (see below; Reed 1990).

The levels of $\mathrm{H}$ complex decrease as $\mathrm{E}$ complex accu- 

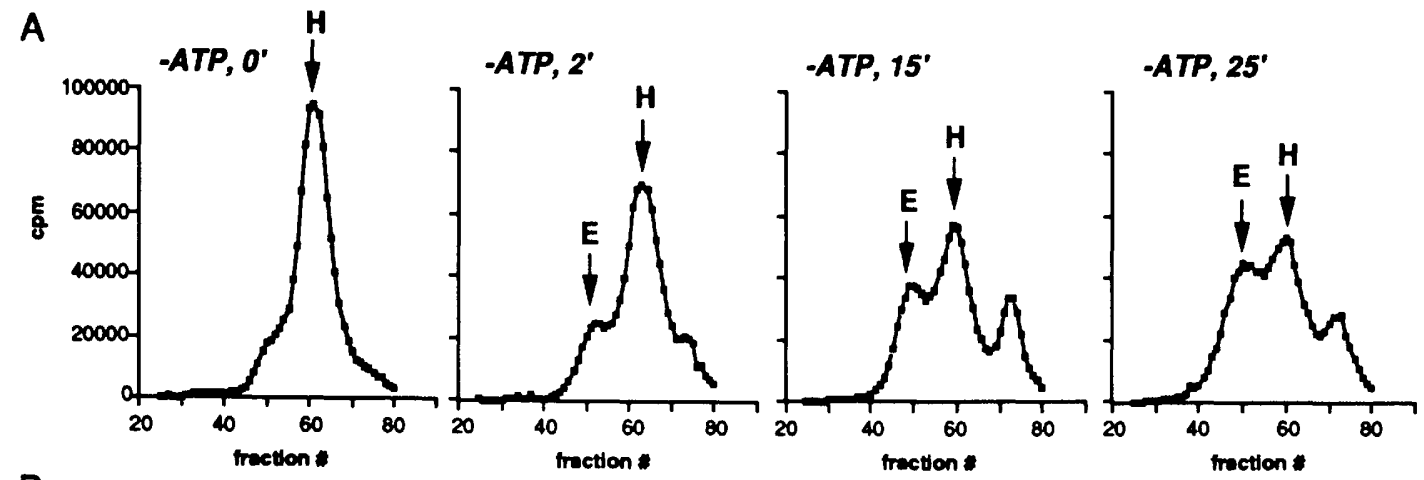

B
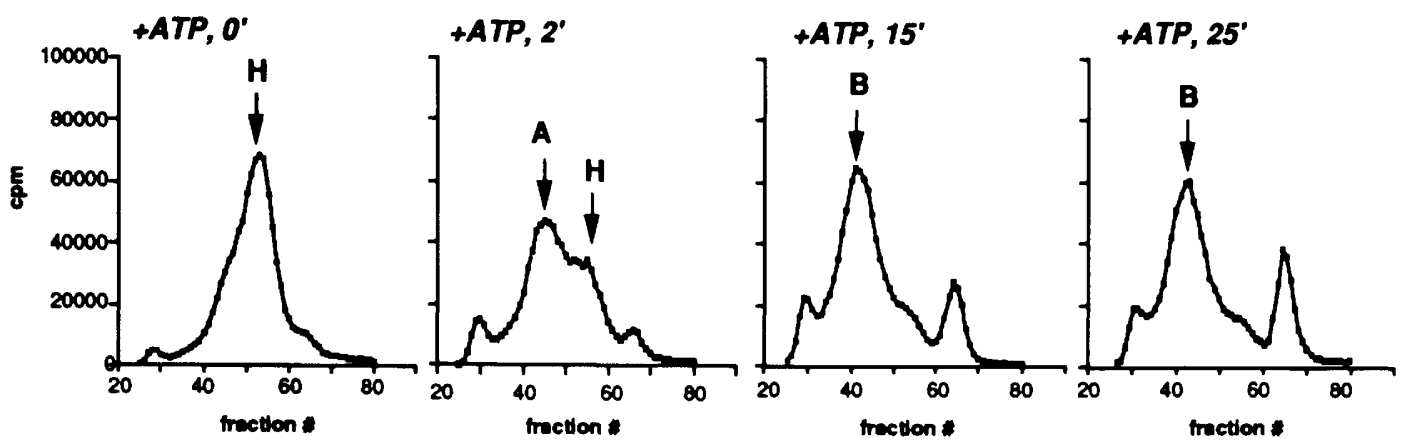

Figure 1. Time course of splicing complex assembly detected by gel filtration. Splicing reactions (100 $\mu$ l) containing $200 \mathrm{ng}$ of ${ }^{32} \mathrm{P}$-labeled AdML pre-mRNA were incubated for the times indicated in either the absence $|A|$ or presence $\{B \mid$ of ATP. Reactions were then fractionated by gel filtration (see Materials and methods). The peaks containing E, A, B, and H complexes are indicated. The peak observed between fractions 25 and 35 in the + ATP columns are the void volumes of each column and contain aggregated material. This peak is smaller in the - ATP column profiles and varies in size, depending on conditions used for splicing reactions (unpublished observations). The unlabeled peaks that elute after $\mathrm{H}$ complex are degraded RNA. Note that the kinetics of appearance of the complexes, the efficiency of complex assembly, and the amount of degradation that occurs during the splicing reactions can vary with different preparations of nuclear extracts, amount of pre-mRNA added to the reaction, and amount of nuclear extract used in the reaction (S. Michaud and R. Reed, unpubl.).

mulates (Fig. 1A). These data indicate that the premRNA in $\mathrm{H}$ complex is a substrate for $\mathrm{E}$ complex assembly. The peak containing degraded RNA, which elutes after $\mathrm{H}$ complex, also accumulates during the time course (Fig. 1A). This peak may result from degradation of $\mathrm{H}$ complex, E complex, or both.

In the presence of ATP, as reported previously (Konarska and Sharp 1987), the A complex is the first specific complex detected when splicing reactions are fractionated on Tris-glycine native gels (Fig. 2, lane 2). At 15', B complex is also detected (Fig. 2, lane 3) and is present at similar levels by $25^{\prime}$ (Fig. 2, lane 4). In contrast to native gel electrophoresis, A and B complexes are not resolved from one another by gel filtration (Fig. 1B). Instead, these complexes are detected in a peak that elutes between $\mathrm{H}$ complex and the void volume (Fig. 1B). The kinetics of appearance of the 2 ' peak suggests that it corresponds to A complex detected on Tris-glycine native gels (Fig. 2, lane 2). This possibility is supported further by comparison of the snRNP composition of the native gel versus gel filtration-purified complexes (see below). The gel-filtration peaks detected at $15^{\prime}$ and $25^{\prime}$ (Fig. 1B) also contain B complex (see below). However, because A and B complexes cofractionate by gel filtration, we do not know whether the $15^{\prime}$ and $25^{\prime}$ peaks are a mixture of $A$ and $B$ complexes or whether a portion of $B$ complex dissociates to A complex on native gels. Support for the latter possibility is the observation that the relative levels of A and B complex vary significantly when splicing reactions are treated with different amounts of heparin (see below) and under different electrophoretic conditions (S. Michaud and R. Reed, unpubl.).

Summarizing the data presented above, in reactions lacking ATP, H and E complexes are resolved by gel filtration, whereas only one complex is detected on native gels. In reactions containing ATP, $\mathrm{H}, \mathrm{A}$, and B complexes are resolved on native gels, whereas $A$ and $B$ complexes cofractionate by gel filtration. C complex, which contains the splicing intermediates, has been characterized previously by gel filtration (Reed 1990) and by native gel electrophoresis (Lamond et al. 1987). Interestingly, all of the splicing-specific complexes, E, A, B, and C, elute in about the same gel-filtration fractions, despite the fact that the complexes differ in snRNP composition (see below; Reed 1990).

To identify the snRNAs in each of the complexes detected by gel filtration, we employed a two-step, affinity chromatography procedure similar to that used previ- 


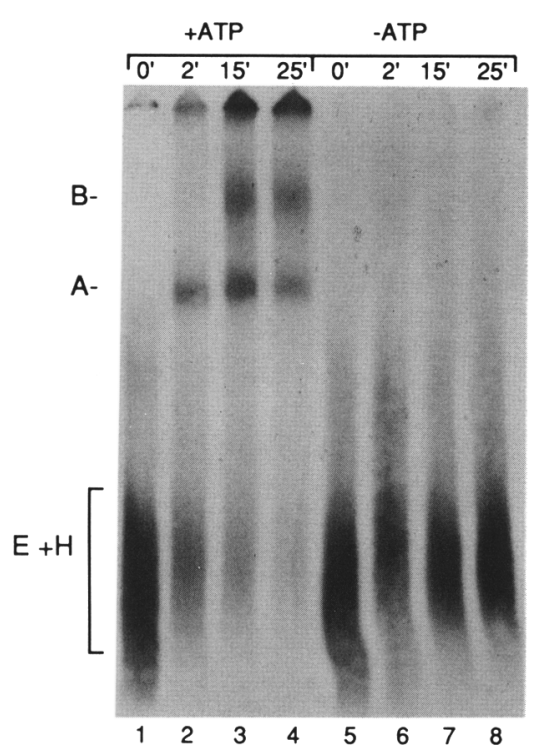

Figure 2. Time course of splicing complex assembly detected by native gel electrophoresis. Splicing reactions $(25 \mu l)$ containing $50 \mathrm{ng}$ of ${ }^{32} \mathrm{P}$-labeled AdML pre-mRNA were incubated for the times indicated in either the presence (lanes 1-4) or absence (lanes 5-8) of ATP. Heparin was then added, and 2.5- $\mu$ l aliquots of each reaction were fractionated by native gel electrophoresis (see Materials and methods; Konarska and Sharp 1987). The bands corresponding to $\mathrm{A}$ and $\mathrm{B}$ and $\mathrm{E}+\mathrm{H}$ complexes are indicated. On the basis of gel filtration data (see text and Fig. 1), E and $\mathrm{H}$ complexes cofractionate on native gels.

ously to characterize splicing complexes (Fig. 3; Reed 1990). In this method, AdML pre-mRNA is hybridized to a biotinylated $2^{\prime}$-O-methyl oligoribonucleotide complementary to a portion of the exon (Barabino et al. 1990). Splicing complexes are then assembled, fractionated by gel filtration, and affinity-purified by binding to avidinagarose. To determine how stably the different snRNAs are associated with each complex, bound complexes were washed in either low salt (150 mM; Fig. 3, lanes 1-6) or higher salt $(250 \mathrm{~mm}$; Fig. 3, lanes $7-12)$. We note that a band designated $X$ is present immediately below $\mathrm{U} 1$ snRNA in all of the samples. This band, which may be a breakdown product of Ul snRNA, is present in our nuclear extracts (data not shown; for further explanation, see legend to Fig. 3).

In a previous study, E complex was identified as an ATP-independent complex that assembled on $\beta$-globin pre-mRNA (Reed 1990). This complex contained higher levels of U1 snRNP than affinity-purified spliceosomes but lower levels of U2, U4, U5, and U6 snRNPs (Reed 1990). In the study reported here, AdML pre-mRNA is assembled into an ATP-independent complex (designated E complex; Fig. 1A) that fractionates by gel filtration similarly to $\mathrm{E}$ complex detected on $\beta$-globin (Reed 1990 ). In addition, this complex, formed either at $2^{\prime}$ or $15^{\prime}$ on AdML pre-mRNA, has the same snRNA composition (Fig. 3, lanes 3 and 4, respectively) as E complex assembled on $\beta$-globin (Reed 1990). Thus, we conclude that this ATP-independent complex detected on AdML correponds to E complex.

Affinity-purified A complex contains $U 1$ and $U 2$ snRNPs (Fig. 3, lane 5). Although the levels of U2 snRNP are similar to those in E complex, the levels of U1 snRNP are substantially lower (Fig. 3, cf. lanes 3 and 5).

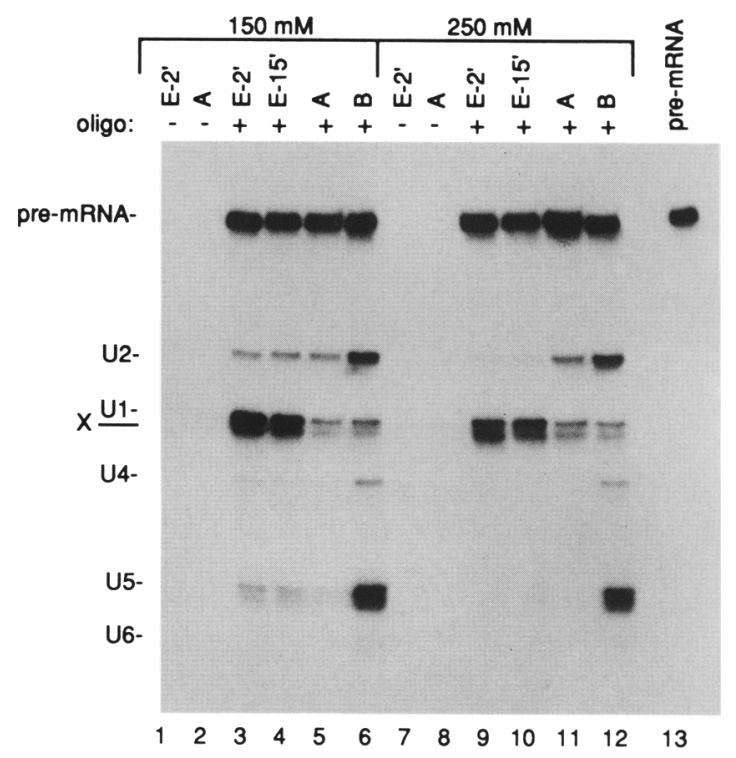

Figure 3. SnRNA composition of E, A, and B complexes. E, A, and $B$ complexes were assembled on ${ }^{32}$ p-labeled AdML premRNA that had been prehybridized to a biotinylated 2 '-Omethyl oligoribonucleotide. Complexes were isolated by gel filtration and affinity-purified by binding to avidin-agarose (see Materials and methods). For control reactions, complexes were assembled on pre-mRNA lacking the biotinylated oligoribonucleotide. Complexes bound to avidin-agarose were washed in $150 \mathrm{~mm}$ salt (lanes 1-6) or $250 \mathrm{~mm}$ salt (lanes 7-12). Total RNA was then prepared from equivalent amounts of each complex, end-labeled with ${ }^{32} \mathrm{pCp}$ and RNA ligase, and fractionated on an $8 \%$ denaturing polyacrylamide gel. Relevant bands were quantitated by Phosphorimager analysis. (Lanes 1,7) E complex formed at 2-min time point, - oligo; (lanes 2,8) A complex, - oligo; (lanes 3,9) E complex formed at 2-min time point, + oligo; (lanes 4,10) E complex formed at 15 -min time point, + oligo; (lanes 5,11) A complex, + oligo; (lanes 6,12) B complex, +oligo; (lane 13) an aliquot of the gel filtration fraction containing E complex. This lane is a marker for the pre-mRNA. The bands corresponding to the snRNAs and pre-mRNA are indicated. We note that the presence of U6 snRNA, which does not 3 '-end-label efficiently (Grabowski and Sharp 1986), was detected in B complex on long exposures of the autoradiograph. The band below U1 snRNP $(X)$ is present in the nuclear extracts prepared from the HeLa cells that we are currently using (see Materials and methods/ but was not observed in extracts prepared previously (Reed et al. 1988; Reed 1990). This band may be a breakdown product of UI snRNA, as the relative levels of Ul snRNA and $X$ are about the same in each complex. Except for $X$, we observed the same snRNA composition of $\mathrm{E}$ and $\mathrm{B}$ complexes in the current and previous nuclear extracts /data not shown). The A complex was not isolated in these previous studies. 
Affinity-purified B complex contains U2, U4, U5, and U6 snRNPs at levels higher than those detected in E or A complexes and similar amounts of Ul snRNP as in A complex (Fig. 3, lane 6). When splicing reactions are fractionated on Tris-glycine native gels, A complex contains U2 snRNP while B complex contains U2, U4, U5, and U6 snRNPs (Konarska and Sharp 1987). Thus, the A and $B$ complexes detected by gel filtration have the same composition as the corresponding complexes detected by native gels except that Ul snRNP is present in the gel filtration-purified complexes.

When the affinity-purified complexes were washed in higher salt, the levels of snRNAs did not change substantially in A and B complexes (Fig. 3, cf. lanes 5 and 6 with lanes 11 and 12). In contrast, U2 snRNA is differentially reduced in $\mathrm{E}$ complex relative to $\mathrm{A}$ and $\mathrm{B}$ complexes (Fig. 3 , cf. lanes 3-6 with lanes 9-12). Notably, however, the levels of U1 snRNA remain at least twice as high in E complex as is seen in either of the ATP-dependent complexes (Fig. 3, cf. lanes 10-12). This association of Ul snRNP with $\mathrm{E}$ complex appears to be specific, as high levels of this snRNP are not found in complexes assembled on pre-mRNA that contains splice site mutations (S. Michaud and R. Reed, in prep). These data suggest that more than one U1 snRNP may be present in each $\mathrm{E}$ complex or that a fraction of the A and $\mathrm{B}$ complexes lacks this snRNP. We also note that the levels of $U 2$ snRNP appear to be lower in A complex than in B complex (Fig. 3, cf. lanes 5 and 6). This may be the result of contamination of A complex with $\mathrm{H}$ complex, which lacks snRNPs. In any case, a careful quantitative analysis of both snRNA and pre-mRNA levels will be required to determine the actual stoichiometries of the different snRNAs in each complex. From our data, in which we compared the salt stability of the different snRNPs in each complex, we can conclude that Ul snRNP is stably associated with E complex, $\mathrm{U} 1$ and $\mathrm{U} 2$ snRNPs are stably associated with A complex, and U1, U2, U4, U5, and U6 snRNPs are stably associated with $B$ complex.

Previous studies showed that B complex is a functional intermediate in the splicing reaction (Abmayr et al. 1988). To determine whether H, E, and A complexes are also functional intermediates, in vitro complementation experiments were carried out (Figs. 4 and 5). In these experiments we asked whether the pre-mRNA in each complex could be chased into spliceosomes and/or spliced products under conditions that naked pre-mRNA could not. The complementing extract consisted of a normal splicing extract that had been preincubated with different amounts of competitor RNA. The competitor contained exon 1 and the $5^{\prime}$ portion of intron 1 from $\beta$-globin (Figs. 4 and 5) or AdML (data not shown) premRNA. In another study, we showed that specific ATPindependent and ATP-dependent complexes assemble on these RNAs (S. Michaud and R. Reed, in prep.). However, because they are not functional splicing substrates, these RNAs should titrate splicing components required for early steps in spliceosome assembly but not those required for subsequent steps of the reaction.

Initially, we carried out experiments to determine

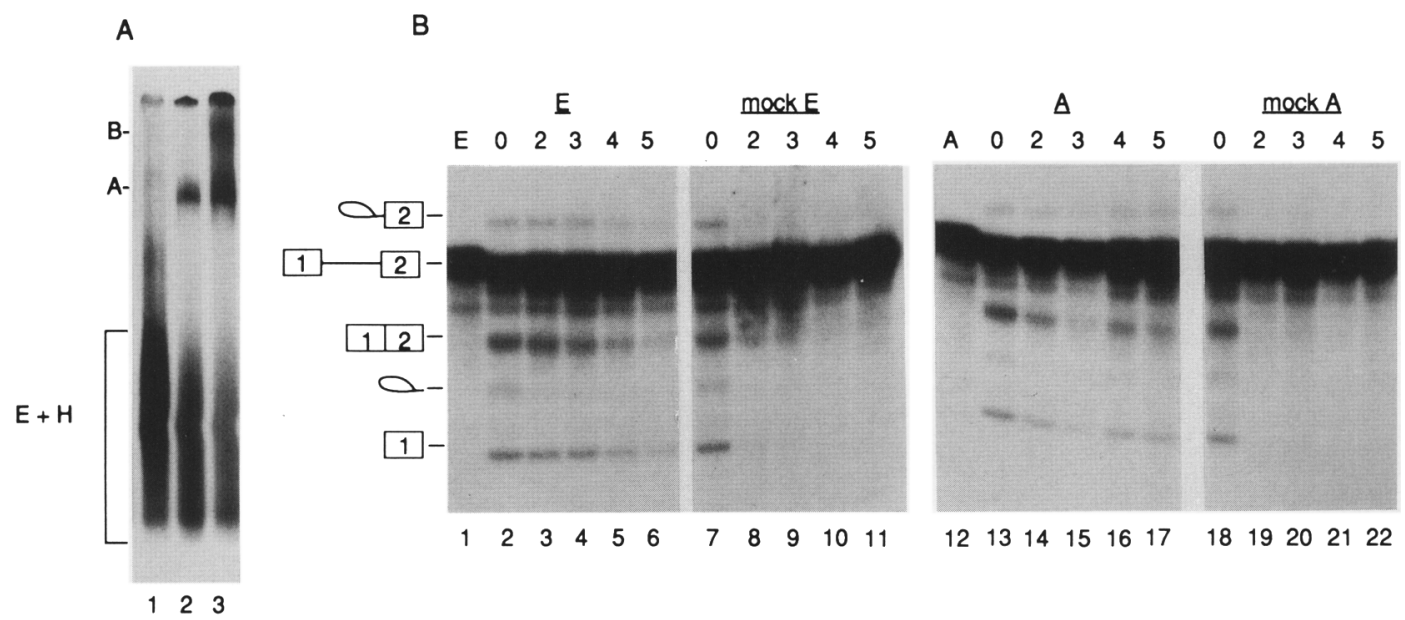

Figure 4. Pre-mRNA is committed to the splicing pathway after incubation in splicing reactions containing or lacking ATP. $(A)$ AdML pre-mRNA ( $30 \mathrm{ng}$ ) was incubated for $10 \mathrm{~min}$ in a splicing reaction (25 $\mu$ l) lacking ATP (lane 1), or for $2 \mathrm{~min}$ (lane 2 ) or $15 \mathrm{~min}$ (lane 3 ) in splicing reactions $(25 \mu \mathrm{l})$ containing ATP. An aliquot of each reaction was mixed with heparin and then fractionated by native gel electrophoresis. $(B)$ An aliquot of the $\mathrm{E}$ complex reaction shown in $A$ (lane 1 ) or the A complex reaction shown in $A$ (lane 2) was diluted 12.5-fold into complementation reactions ( $E$ and $A$, lanes 1-6 and 12-17, respectively). In the control mock reactions (mock E and mock A, lanes 7-11 and 18-22, respectively), nuclear extract and AdML pre-mRNA were not incubated together prior to 12.5 -fold dilution into the complementation reaction. All of the components in the A and the mock A complementation reactions are identical to one another. Similarly, the components in the E and mock E complementation reactions are identical to one another/see Materials and methods). The nuclear extract in the complementation reaction had been preincubated with the amounts of competitor RNA indicated above each lane in $0.1-\mu \mathrm{g}$ units (lanes 2-6,8-11,13-17,19-22). The complementation reactions were incubated under splicing conditions for $60 \mathrm{~min}$, except for lanes 1 and 12, which were not incubated. RNA was then prepared and fractionated on a $15 \%$ denaturing polyacrylamide gel. The bands correponding to pre-mRNA and the splicing intermediates and products are shown. 

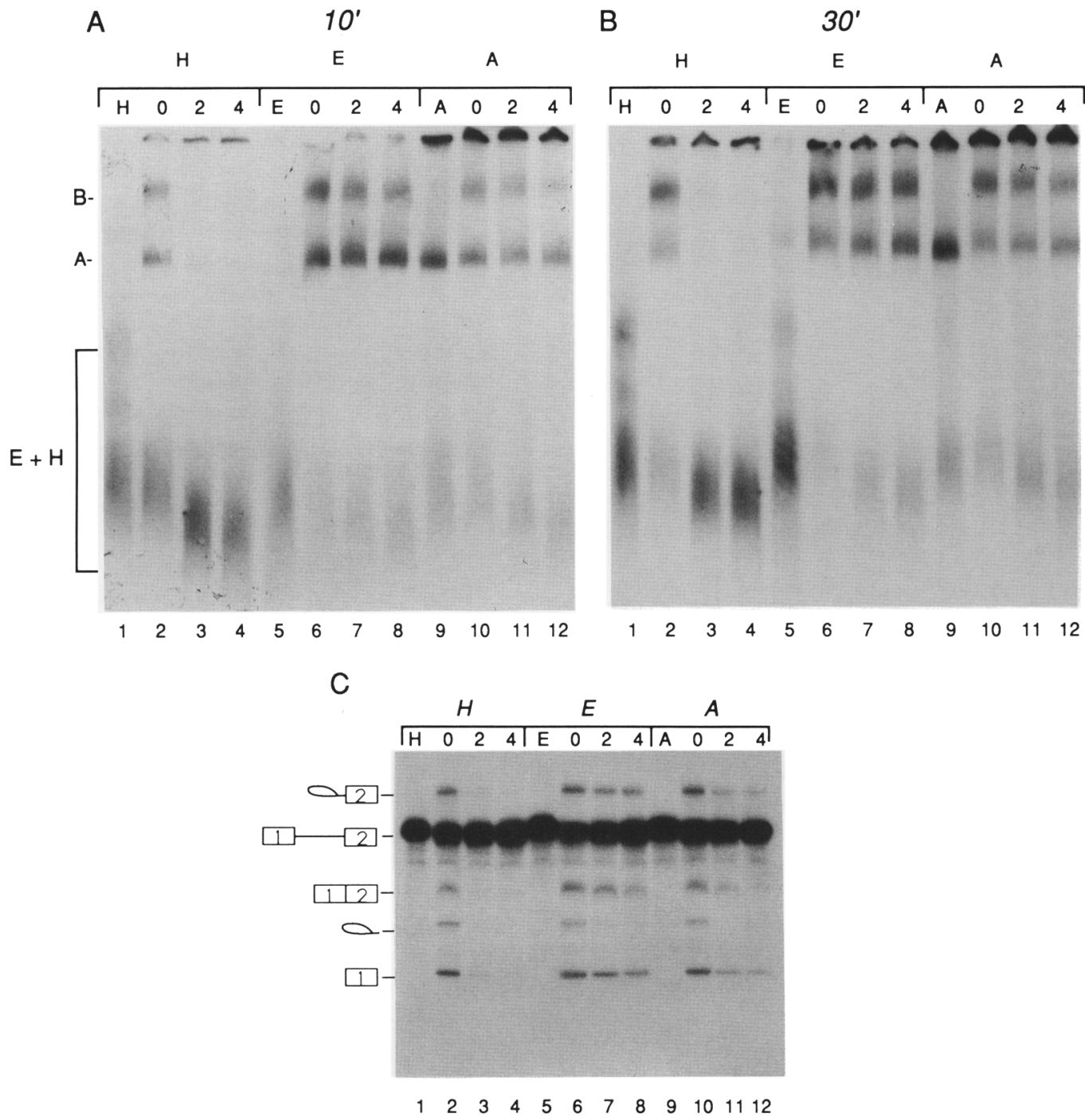

Figure 5. Gel filtration-purified $\mathrm{A}$ and $\mathrm{E}$ complexes are committed to spliceosome assembly and splicing. $(A, B)$ Complex assembly. Aliquots of gel filtration fractions containing $\mathrm{H}, \mathrm{E}$, or A complex assembled on AdML pre-mRNA were incubated under splicing conditions in 50- $\mu \mathrm{l}$ complementation reactions. Nuclear extracts in the complementation reactions were preincubated with the amounts of competitor RNA indicated above each lane in $0.1-\mu \mathrm{g}$ units. At $10 \mathrm{~min}(A)$ and $30 \mathrm{~min}(B) 10-\mu l$ aliquots were removed, mixed with heparin, and fractionated by native gel electrophoresis $[\mathrm{H}$ (lanes $2-4)$; $\mathrm{E}$ (lanes $6-8)$; $\mathrm{A}($ lanes $10-12) \mid \mathrm{H}, \mathrm{E}$, and $\mathrm{A}$ complexes, mixed with complementing extract, but not incubated, are shown in $A$ and $B$ (lanes 1,5 , and 9 , respectively). We note a faint band that fractionates slightly above A complex is sometimes detected in E complex (e.g., $B$, lane 5 ). This band could represent a minor fraction of $E$ complex that is stable to native gel fractionation. $|C|$ Splicing. The complementation reactions from $B$ were incubated for 30 additional minutes. RNA was then prepared and fractionated on a $15 \%$ denaturing polyacrylamide gel $[\mathrm{H}(\mathrm{lanes} 2-4) ; \mathrm{E}(\mathrm{lanes} 6-8) ; \mathrm{A}$ (lanes 10-12)]. RNA prepared from the untreated H, E, and A complexes is shown in lanes 1, 5, and 9, respectively. The bands correponding to pre-mRNA and the splicing intermediates and products are shown.

whether a stable complex, committed to the splicing pathway, assembles under conditions in which $\mathrm{E}$ or $\mathrm{A}$ complexes form (Fig. 4). This was achieved by incubating AdML pre-mRNA in splicing extracts in the presence or absence of ATP and then diluting a small aliquot of this reaction into a complementation reaction. As a control, mock reactions were carried out in which the pre-mRNA and extract were not incubated together prior to their dilution into the complementation reactions (see Materials and methods).
When an aliquot of a reaction that was incubated in the absence of ATP was fractionated by native gel electrophoresis, only the H/E band was detected (Fig. 4A, lane 1) while A complex was detected in an aliquot of a reaction containing ATP (Fig. 4A, lane 2). As expected, only unspliced RNA was observed in each of these cases (Fig. 4B, lanes 1,12 ). In contrast, spliced RNA was readily detected when aliquots of $E$ or $A$ complex reactions (Fig. 4B, lanes 2,13), or either mock reaction (Fig. 4B, lanes 7,181 , were incubated in complementing reactions lack- 
ing competitor RNA. Significantly, however, in complementation reactions containing different amounts of competitor RNA, spliced RNA was efficiently generated from $E$ and A reactions (Fig. 4B, lanes 3-6,14-17) relative to that observed at the corresponding competitor concentrations with the mock reactions (Fig. 4B, lanes 8-11,19-22). Thus, we conclude that pre-mRNA, incubated in either A or E complex reactions, forms a complex that is committed to the splicing pathway.

To determine whether any of these complexes could be isolated in a functional form, we carried out in vitro complementation assays using gel filtration-purified $\mathrm{H}$, $\mathrm{E}$, or A complexes. Aliquots of fractions containing each complex were incubated under splicing conditions for $10^{\prime}, 30^{\prime}$, or $60^{\prime}$ in extracts that had been preincubated with the amounts of competitor indicated above each lane (in 0.1- $\mu$ g units), and spliceosome assembly or splicing was then assayed (Fig. 5A,B,C, respectively). When $\mathrm{H}$ complex (Fig. 5A,B, lanes 1 ) was incubated under normal splicing conditions, $\mathrm{A}$ and $\mathrm{B}$ complexes were formed (Fig. 5A,B, lanes 2) and spliced RNA was detected (Fig. 5C, lane 2). In contrast, when $\mathrm{H}$ complex was incubated in complementing extracts that contained competitor RNA, barely any $A$ and $B$ complexes were detected (Fig. $5 \mathrm{~A}, \mathrm{~B}$, lanes 3,4 ), nor were significant amounts of spliced RNA observed (Fig. 5C, lanes 3,4). Strikingly, however, when either gel filtration-isolated $\mathrm{E}$ or A complexes (Fig. $5 \mathrm{~A}, \mathrm{~B}$, lanes 5,9 | were incubated in complementation reactions containing competitor RNA, the levels of spliceosome assembly and splicing were similar to those observed in the absence of competitor RNA (Fig. 5A-C, lanes $6-8$ and $10-12$, respectively|. To ensure that the competitor-titrated extracts were actually complementing $\mathrm{E}$ complex and not factors present in the gel-filtration fractions, we added naked pre-mRNA to E complex fractions and carried out the complementation assay. In these experiments the naked pre-mRNA was not assembled into A or B complexes (data not shown).

These data indicate that gel filtration-purified A and E complexes are committed to spliceosome assembly and splicing. E complex is a functional precursor to both $\mathrm{A}$ and $B$ complexes, whereas $A$ complex is a precursor to $B$ complex. In contrast, $\mathrm{H}$ complex was not shown to be a functional intermediate by these assays. However, the pre-mRNA in $\mathrm{H}$ complex is not assembled into an irreversible nonfunctional complex, because $\mathrm{H}$ complex forms A and B complexes and spliced RNA when incubated in extracts lacking competitor.

Additional evidence that $\mathrm{E}$ complex commits premRNA to the spliceosome assembly pathway was provided by a comparison of the kinetics of spliceosome assembly between pre-mRNA (data not shown) and $\mathrm{H}$ and E complexes (Fig. 6). Gel-filtration column fractions, containing either $\mathrm{H}$ or $\mathrm{E}$ complexes, were incubated under splicing conditions for the times indicated and then fractionated by native gel electrophoresis (Figs 6A, $\mathrm{B}$; note that the samples in $A$ and $B$ are identical except that they were treated with either 0.6 or $0.3 \mathrm{mg} / \mathrm{ml}$ of heparin, which affects the relative levels of $A, H$, and $B$ complexes; for further explanation, see below). Figure $6 \mathrm{C}$ shows a graph of the kinetics of $A+B$ complex assembly based on the data shown in Figure 6A. Similar results were obtained from the data in Figure 6B and from several independent experiments (data not shown). We observed the same kinetics of spliceosome assembly with naked pre-mRNA as were observed with $\mathrm{H}$ complex (data not shown). We conclude that $\mathrm{E}$ complex is converted into A complex at a faster initial rate and significantly more efficiently than $\mathrm{H}$ complex or naked premRNA. These results cannot be attributed to differential degradation of the pre-mRNA in $\mathrm{H}$ versus $\mathrm{E}$ complexes as similar amounts of pre-mRNA were present throughout the time course (Fig. 6D).

During the course of our experiments, we routinely observed significant differences in the relative levels of splicing complexes treated with different amounts of heparin prior to native gel electrophoresis. Previous studies have employed heparin concentrations ranging from 0.2 to $5 \mathrm{mg} / \mathrm{ml}$ (Konarska and Sharp 1986; 1987; Kramer 1988; Nelson and Green 1988; Zamore and Green 1989|. To determine systematically the effects of different concentrations of heparin on each splicing complex, we compared identical reactions treated with different amounts of heparin. Figure 6, A and B, shows a comparison of the same samples treated with 0.6 or 0.3 $\mathrm{mg} / \mathrm{ml}$ of heparin. With the higher concentration of heparin, significantly more A complex than B complex is detected, whereas the reverse is true with the lower concentration of heparin (Fig. 6,A and B, respectively, cf. lanes $5,9,10)$. These observations indicate that $B$ complex is at least partially heparin sensitive and that it dissociates to A complex in the higher concentration of heparin. Differences in the ratio of A-H complexes were also observed with different heparin concentrations (data not shown). These data indicate that the amounts of $A$, $\mathrm{B}$, and $\mathrm{H}$ complexes detected on native gels may not accurately reflect the relative amounts of these complexes that actually exist in the splicing reaction.

The studies presented in Figures 5 and 6 provide evidence that $\mathrm{E}$, as well as $\mathrm{A}$, complexes are physiologically relevant to splicing. Two additional observations support this conclusion. First, the efficiency of E-complex assembly on AdML (Fig. 7A), $\beta$-globin (Fig. 7B), and other pre-mRNAs (data not shown) correlates with the efficiency of B-complex assembly on these RNAs. Although $E$ and $B$ complexes are assembled efficiently on AdML, they are inefficiently assembled on $\beta$-globin pre-mRNA (Fig. 7A,B, cf. E/H ratios and B/H ratios; Reed 1990). We note that in other studies of spliceosome assembly, the $\mathrm{B} / \mathrm{H}$ ratio observed with $\beta$-globin pre-mRNA is considerably higher than that observed in Figure 7 (data not shown; Reed and Maniatis 1988; Reed et al. 1988; Reed 1990). However, this higher ratio is observed only when very low amounts of $\beta$-globin pre-mRNA $(40-80 \mathrm{fmoles} /$ $100-\mu l$ reaction) are added to the splicing reaction or when the reactions are incubated for long periods of time (2-2.5 hr, data not shown; Reed et al. 1988; Reed 1990). In contrast, in Figure 7, we compared complex assembly on 1.2 pmole of AdML or $\beta$-globin pre-mRNAs after a short incubation $\left(15^{\prime}\right)$. These data clearly demonstrate 

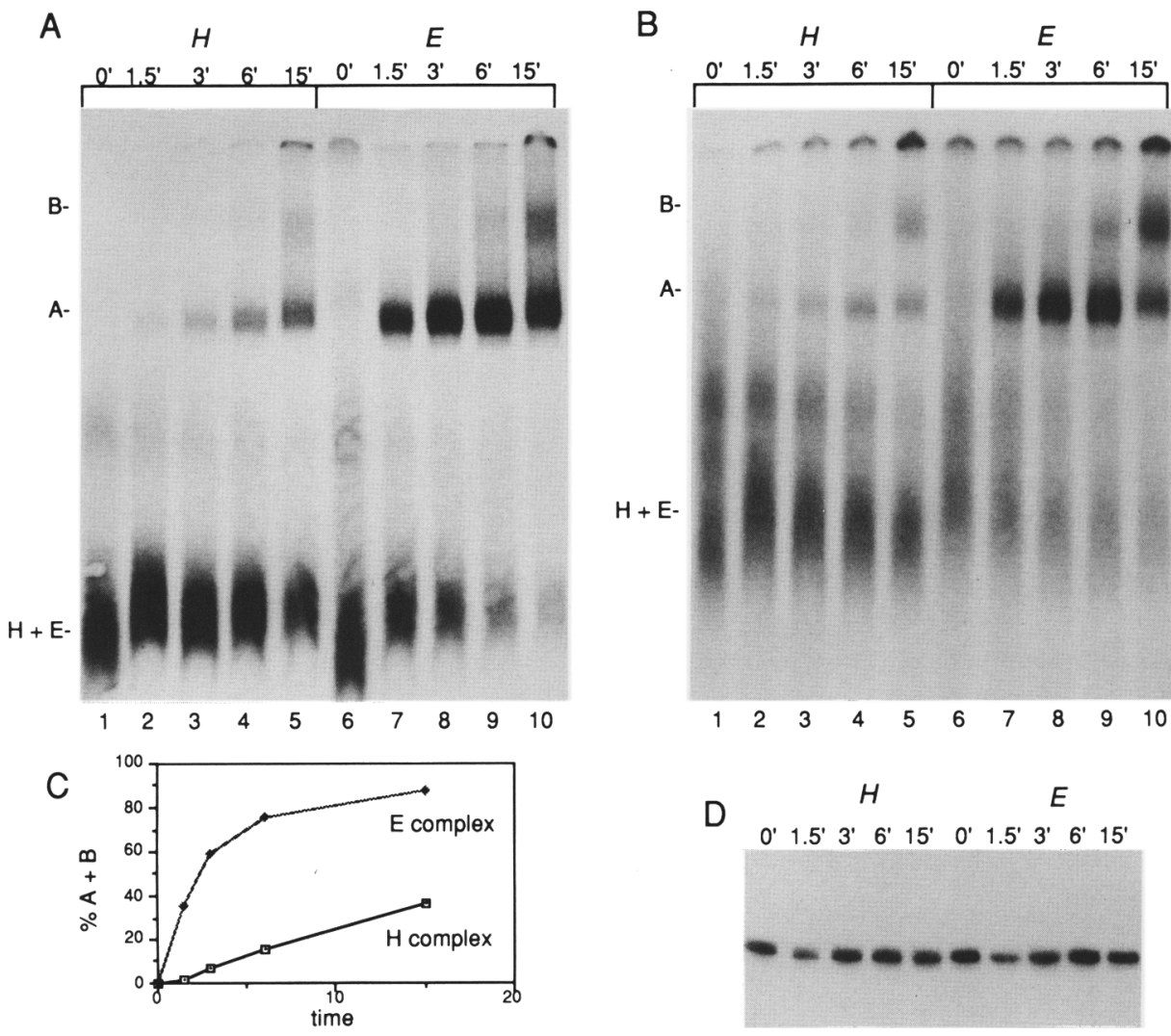

Figure 6. Comparison of the kinetics of spliceosome assembly between gel filtration-isolated $\mathrm{H}$ and $\mathrm{E}$ complexes. $(A, B)$ Aliquots of $\mathrm{E}$ or $\mathrm{H}$ complexes were incubated under splicing conditions for the times indicated, treated with either $0.6(A)$ or $0.3(B) \mathrm{mg} / \mathrm{ml}$ of heparin, and fractionated by native gel electrophoresis. The $\mathrm{A}, \mathrm{B}$, and $\mathrm{H}+\mathrm{E}$ complexes are indicated. $(C)$ Splicing complexes were quantitated by Phosphorimage analysis. Time in minutes is plotted versus the amounts of $\mathrm{A}+\mathrm{B}$ complexes/H $+\mathrm{A}+\mathrm{B}$ complexes $\times 100(\% \mathrm{~A}+\mathrm{B}) .(D)$ Total RNA from an aliquot of each of the samples in $A$ was fractionated on an $8 \%$ denaturing polyacrylamide gel.

that AdML pre-mRNA is assembled into splicing complexes more efficiently than $\beta$-globin.

The conclusion that $\mathrm{E}$ complex is physiologically relevant to the splicing pathway is supported further by the observation that comparable amounts of pre-mRNA are assembled into $E$ complex as are assembled into $B$ complex (Fig. 7A,B; see also Fig. 1A,B). Thus, E-complex assembly cannot be viewed simply as a side reaction that occurs on a minor fraction of the pre-mRNA added to the splicing reaction. Although $\mathrm{E}$ complex assembled on $\beta$-globin pre-mRNA is barely resolved from $\mathrm{H}$ complex, and the amount of $\mathrm{E}$ complex formed is relatively low, the amount of $B$ complex that assembles on $\beta$-globin is correspondingly low. Moreover, E complex assembled on $\beta$-globin pre-mRNA can also be chased into spliced products (data not shown). Thus, these observations are consistent with the conclusion that E complex commits premRNA to the spliceosome assembly pathway. In addition, these data suggest that the efficiency of spliceosome assembly on a particular pre-mRNA is a function of the efficiency of $\mathrm{E}$ complex assembly.

\section{Discussion}

Splicing complexes assembled in vitro have been frac- tionated by a number of methods (Brody and Abelson 1985; Frendewey and Keller 1985; Grabowski et al. 1985; Grabowski and Sharp 1986; Konarska and Sharp 1986, 1987; Pikielny et al. 1986; Reed et al. 1988; Ruby and Abelson 1988; Barabino et al. 1990; Reed 1990). However, only subsets of the known complexes implicated in spliceosome assembly (see Fig. 8) had been detected previously using any single fractionation method. Moreover, depending on the isolation method, the snRNP compositions of splicing complexes vary. Thus, it has been difficult to establish definitively the relationships between complexes isolated by different methods and to establish the composition of each complex. Finally, precursor/product relationships had not been determined directly for complexes involved in the early steps of mammalian spliceosome assembly.

In this and previous studies, gel filtration was used to isolate $\mathrm{H}, \mathrm{A}, \mathrm{B}, \mathrm{C}$, and $\mathrm{E}$ complexes (Abmayr et al. 1988; Reed et al. 1988; Reed 1990). Thus, the entire set of known splicing complexes has now been identified and characterized by one fractionation method. The advantage of using one method is that complexes can be directly compared, thus avoiding inconsistencies that arise by comparing complexes isolated by different approaches. The complexes isolated by gel filtration assem- 
A

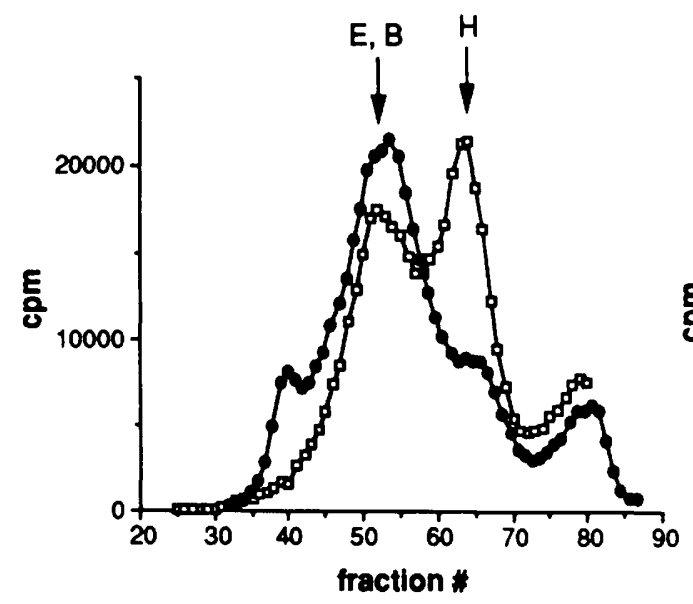

B

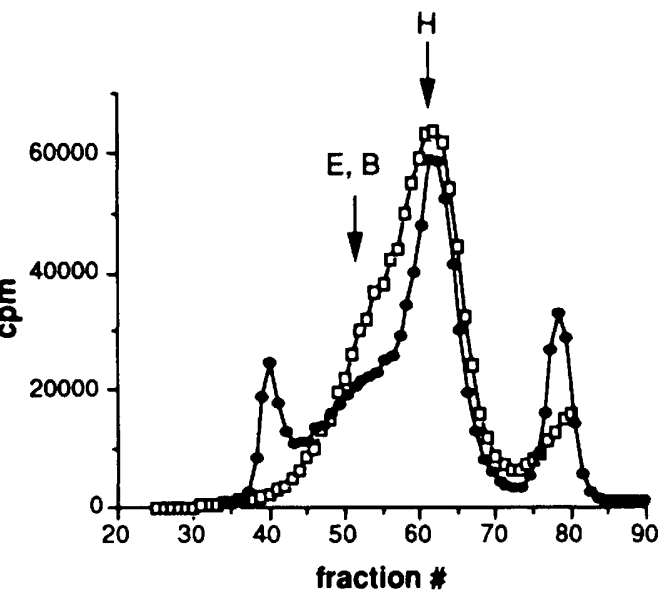

Figure 7. Correlation between efficiency of spliceosome and E complex assembly on different pre-mRNA substrates. Equimolar amounts of AdML pre-mRNA $(A)$ or $\beta$-globin pre-mRNA $|B|(1.2 \mathrm{pmole} / 100-\mu l$ reaction) were incubated under splicing conditions in the presence $(O)$ or absence $(\square)$ of ATP for $15 \mathrm{~min}$ and then fractionated by gel filtration. The peaks corresponding to $H$, E, and B complexes are indicated. The unlabeled peaks that elute before the E and the B complexes in the + ATP column profiles are the void volumes of each column. The unlabeled peaks that elute after H complex are degraded RNA. The + ATP (O) and - ATP ( $\square$ ) column profiles were aligned by superimposing $\mathrm{H}$ complexes. We note that the differences in efficiency of spliceosome assembly between different pre-mRNAs have been observed in every preparation of nuclear extract.

ble in the order $\mathrm{H}, \mathrm{E}, \mathrm{A}, \mathrm{B}$, and C (see Fig. 8; this study; Reed et al. 1988). We show that A and E complexes, but not $\mathrm{H}$ complex, can be isolated and chased into spliced products. E complex can be chased into $\mathrm{A}$ and then into B complex while A complex can be chased into B complex. In previous studies, gel filtration-isolated B and C complexes were also shown to be functional intermediates in the splicing pathway (Abmayr et al. 1988; Reed et al. 1988). Thus, these studies provide direct evidence that mammalian spliceosomes assemble in a stepwise manner as had been proposed primarily on the basis of the temporal appearance of complexes during the splicing reaction (Frendewey and Keller 1985; Konarska and Sharp 1986, 1987; Bindereif and Green 1987).

Although $\mathrm{H}$ complex was not shown to be a functional intermediate by the assays we employed, it is nevertheless possible that some or all of the hnRNP proteins in $\mathrm{H}$ complex could affect spliceosome assembly or splicing. This possibility is suggested by the observation that many of the 20 known hnRNP proteins have distinct sequence preferences (Swanson and Dreyfuss 1988; D. Staknis et al. in prep.) and that these proteins package each pre-mRNA in a transcript-specific manner (Staknis et al., in prep.). This differential binding of hnRNP proteins could, for example, play an essential role in splice site selection by specifying the packaging of highly complex pre-mRNAs that contain numerous cryptic splice sites or multiple splice site choices. This type of role for $\mathrm{H}$ complex would not have been detected in our studies.

\section{E complex commits pre-mRNA} to spliceosome assembly

In yeast, functional studies of the early steps in spliceo- some assembly demonstrated directly that an ATP-independent complex commits pre-mRNA to the splicing pathway (Seraphin and Rosbash 1989, 1991). Several observations indicate that in mammals, E complex commits pre-mRNA to the splicing pathway. First, E complex is the earliest specific splicing complex detected. Second, isolated E complex can be chased into A and B complexes and into spliced products, under conditions in which naked pre-mRNA cannot. Third, E complex is assembled into A complex at a faster initial rate and significantly more efficiently than is $\mathrm{H}$ complex or naked pre-mRNA. Fourth, the amount of pre-mRNA that assembles into E complex is about the same as that assembled into spliceosome complexes. Finally, the efficiency of $E$ complex assembly correlates with the efficiency of spliceosome assembly on different pre-mRNAs. These observations, coupled with the fact that E complex assembles in the absence of ATP and contains Ul snRNP (see below), suggest that E complex may be the mammalian equivalent of the yeast commitment complex (Seraphin and Rosbash 1989).

The observation that E complex accumulates to detectable levels only in the absence of ATP indicates that this complex is rapidly assembled into A complex during the normal splicing reaction. This conclusion is supported by our kinetic study in which we observed rapid assembly of A complex from gel filtration-isolated $\mathrm{E}$ complex.

\section{snRNP composition of functional splicing complexes}

Each splicing complex detected by gel filtration has been purified further by affinity chromatography to determine its snRNP composition (this study; Reed 1990). The 


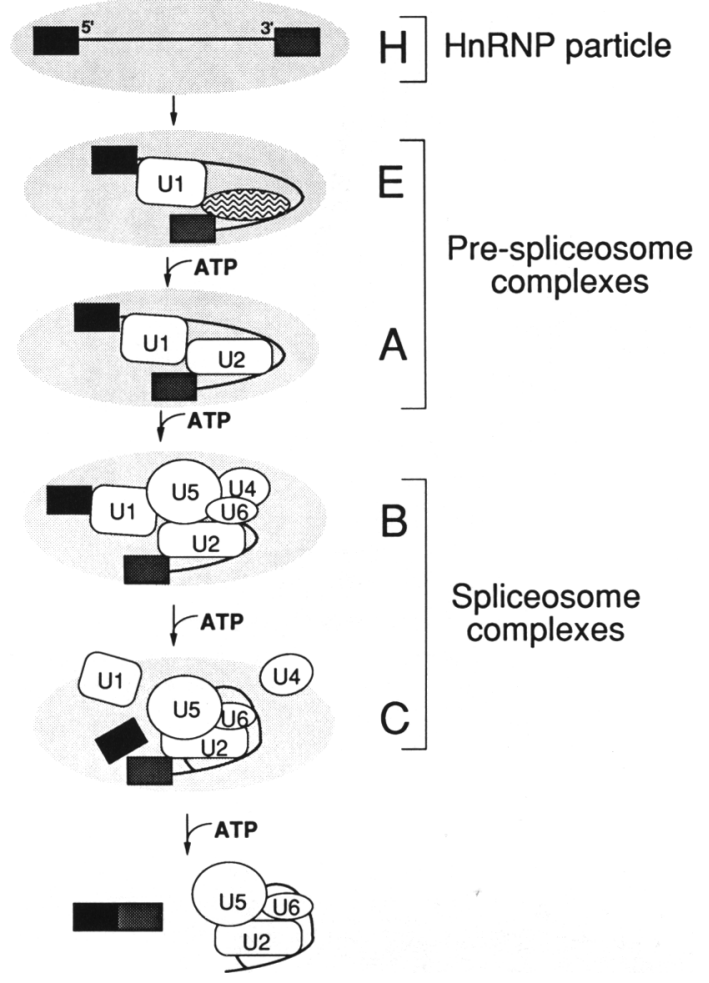

Figure 8. Steps in mammalian spliceosome assembly. The order of assembly, and the snRNPs stably bound in gel filtrationpurified complexes, are shown. hnRNP proteins, present in $\mathrm{H}$ complex, are indicated by the shaded oval. As depicted, at least some of these proteins remain bound in pre-spliceosome and spliceosome complexes (M. Bennett and R. Reed, unpubl.). The 5 '- and $3^{\prime}$-splice sites may be juxtaposed in E complex, and this may be mediated by another splicing factor (indicated by the shaded sphere; see text). U1 and U4 snRNPs become associated more loosely or may even dissociate by the time $\mathrm{C}$ complex is detected (Lamond et al. 1988; Blencowe et al. 1989; Reed 1990). The lariat-intron complex, containing U2, U5, and U6 snRNPs, has not been identified by gel filtration but was characterized by native gel electrophoresis (Konarska and Sharp 1987). ATP is required at four distinct steps in the splicing pathway as indicated (Abmayr et al. 1988; Reed et al. 1988; S. Michaud and R. Reed, unpubl.). Boxes indicate exons; the line indicates the intron. The interactions between snRNPs were drawn arbitrarily.

snRNPs stably associated with each complex are shown in Figure 8. E complex is specifically enriched in U1 snRNP relative to the other splicing complexes (this study; Reed 1990). Unexpectedly, E complex also contains significant levels of U2 snRNP relative to those observed in A and B complexes (this study; Reed 1990). However, U2 snRNP dissociates from E complex treated with $250 \mathrm{~mm}$ salt, whereas U1 snRNP is more salt stable. The presence of $U 1$ and U2 snRNPs in E complex is specific because these snRNPs do not bind to RNAs containing mutations in the splice sites (S. Michaud and R. Reed, in prep). Further studies are required to determine whether the U2 snRNP in E complex undergoes a stabilization to form A complex or whether U2 snRNP is actually added in a stepwise manner. It is possible that in the absence of ATP, Ul snRNP binds to pre-mRNA as part of a multi-snRNP particle containing $U 1$ and $U 2$ snRNPs; in the presence of ATP, these multi-snRNP particles dissociate, resulting in individual binding of the snRNPs. This is plausible as there is ample precedence for ATP-dependent recycling of multi-snRNP particles (Black et al. 1985; Krainer and Maniatis 1985; Konarska and Sharp 1987, 1988).

In contrast to $E$ complex, the snRNPs present in affinity-purified A and B complexes are not significantly affected by salt treatment. Both U1 and U2 snRNPs are stably associated with A complex while U1, U2, U4, U5, and $\mathrm{U} 6$ are stably associated with $\mathrm{B}$ complex. Previous studies have suggested that Ul (Bindereif and Green 1987; Reed 1990) and U4 (Pikielny et al. 1986; Cheng and Abelson 1987; Lamond et al. 1988; Blencowe et al. 1989; Reed 1990) snRNPs dissociate, or at least associate less tightly, with the spliceosome by the time C complex is detected (Fig. 8). Cleavage at the 5 '-splice site and lariat formation occur at this time (Konarska and Sharp 1987). It has been proposed that U6 snRNA participates directly in this catalysis, which necessitates disrupting the U4/ U6 base-pairing interactions in C complex (Brow and Guthrie 1989). The role of U1 snRNP in each of the different splicing complexes is not known, though genetic studies have shown that this snRNP participates directly in 5 '-splice site recognition by base-pairing interactions (Zhuang and Weiner 1986; Seraphin et al. 1988; Siliciano and Guthrie 1988). The observation that $\mathrm{Ul}$ is the first snRNP stably bound to pre-mRNA indicates that it is involved minimally in the initial events of spliceosome formation.

\section{Yeast and mammalian spliceosome assembly}

Our studies suggest that in mammals, as in yeast, an ATP-independent complex containing stably bound U1 snRNP commits pre-mRNA to spliceosome assembly (this study; Seraphin and Rosbash 1989, 1991). Remarkably, studies in yeast suggest that the $5^{\prime}$ and $3^{\prime}$ portions of the intron are juxtaposed as early as commitment complex assembly, prior to $\mathrm{U} 2 \mathrm{snRNP}$ binding. This proposal is based on the observation that the branchpoint sequence, as well as the $5^{\prime}$-splice site, are required for efficient Ul snRNP binding and commitment complex formation (Seraphin and Rosbash 1989; Ruby and Abelson 1988). As indicated in Figure 8, the $5^{\prime}$ - and $3^{\prime}$-splice sites in mammals, as in yeast, may be juxtaposed at the time of E-complex assembly. This proposal is based on the observation that U1 snRNP binding and E-complex assembly occur independently on RNAs containing only a $5^{\prime}$ - or a $3^{\prime}$-splice site (S. Michaud and R. Reed, in prep.), which suggests that these regions communicate in the intact pre-mRNA. It is not known, in either yeast or mammals, whether Ul snRNP interacts directly with both the $5^{\prime}$-splice site and the $3^{\prime}$ portion of the intron or whether another factor mediates interactions between $\mathrm{U} l$ snRNP and the 3 ' portion of the intron. For example, in mammals, it is possible that the loosely bound $\mathrm{U} 2$ 
snRNP present in E complex may be involved in this recognition. Alternatively, the mammalian splicing factor U2AF, which binds to the pyrimidine tract at the 3 '-splice site and mediates U2 snRNP binding (Zamore and Green 1991), may be involved. Based on the observation that U2AF binds to pre-mRNA in the absence of ATP (Zamore and Green 1989), this factor is likely to be a component of $\mathrm{E}$ complex.

Although the splicing pathway appears to have been conserved between yeast and mammals, the structure of the pre-mRNAs in these organisms differs significantly. In higher eukaryotes most pre-mRNAs are quite complex, containing multiple introns that are often alternatively spliced, whereas in yeast the few pre-mRNAs that are spliced usually contain a single intron. In the studies reported here, we observed dramatic differences in the efficiency of spliceosome assembly on different premRNAs. Assembly was efficient on AdML and relatively inefficient on $\beta$-globin pre-mRNA. Considering these single-intron pre-mRNAs as models, it is possible that each intron in pre-mRNAs containing multiple introns assembles spliceosomes with different efficiencies. These variable efficiencies may, in turn, affect the pattern of splice site selection for the entire pre-mRNA. Our data suggest that this variability in efficiency is first apparent with E-complex assembly. A detailed analysis of the assembly and composition of $\mathrm{E}$ complex is therefore likely to provide clues to the mechanisms of splice site selection in complex pre-mRNAs.

\section{Materials and methods}

\section{Plasmids}

Plasmid pAdML was constructed by subcloning an EcoRISau3A fragment from pBSAd10 (gift from $M$. Konarska) into the EcoRI and BamHI sites of SP72 (Promega Biotech). This fragment contains exon 1 ( 71 nucleotides), intron 1 (97 nucleotides), and exon 2 (45 nucleotides) derived from the AdML transcription unit. DNA was linearized with BamHI $\mid+213$ in pAdML) for transcription. Plasmid T7H $\beta$ (Reed et al. 1988) contains exon 1 (155 nucleotides), intron 1 (130 nucleotides), and exon 2 (205 nucleotides/ derived from the human $\beta$-globin transcription unit. $\mathrm{T} 7 \mathrm{H} \beta$ DNA was linearized at an $X$ hoI site in the middle of the intron for transcription of the competitor RNA used in Figures 4 and 5, and with BamHI for transcription of the whole pre-mRNA.

\section{Pre-mRNA synthesis and in vitro splicing reactions}

Plasmids were transcribed with $\mathrm{T} 7$ polymerase (Melton et al. 1984), and RNAs were capped during transcription as described (Konarska et al. 1984). In vitro splicing reactions were carried out according to Krainer et al. (1984), except that polyvinylalcohol was omitted. Reactions contained $30 \%$ nuclear extract and were incubated at $30^{\circ} \mathrm{C}$ for times indicated in the figure legends. For assembly of $\mathrm{E}$ complexes, reactions lacked ATP, $\mathrm{MgCl}_{2}$, and creatine phosphate. Unless indicated otherwise, reactions were $100-125 \mu \mathrm{l}$ and contained $1.3-1.8 \mathrm{fmole} / \mu \mathrm{l}$ of ${ }^{32} \mathrm{P}$ labeled pre-mRNA. ATP depletion of nuclear extracts was assayed by incubating $1.5 \mu \mathrm{l}$ of $\left[\gamma^{-32} \mathrm{P} \mid \mathrm{ATP}\right.$ with a $\left.50-\mu\right]$ aliquot of nuclear extract either containing or lacking $2 \mu \mathrm{l}$ of a hexokinase-glucose mixture $110 \mathrm{mg} / \mathrm{ml}$ of hexokinase in $250 \mathrm{~mm}$ glu- cose). Reactions were incubated at room temperature for 20 min. Fifty microliters of $10 \%$ trichloroacetic acid was added to a $5-\mu \mathrm{l}$ aliquot of these reactions, and the mixture was centrifuged for $1 \mathrm{~min}$ in a microcentrifuge. One microliter of each sample was applied to a $\left[\gamma_{-}{ }^{32} \mathrm{P}\right]$ ATP polyethyleneimine cellulose plate. $\left[\gamma^{-}{ }^{32} \mathrm{P}\right] \mathrm{ATP}$ and ${ }^{32} \mathrm{P}$ were used as standards, and plates were chromatographed in $\mathrm{LiCl}$ buffer until the solvent front was near the top of the plate. Depletions were $>90 \%$ whether or not hexokinase and glucose were added to the nuclear extracts. We therefore used extracts without addition of hexokinase and glucose.

\section{Purification of splicing complexes}

For gel filtration of splicing complexes, in vitro splicing reactions $(100-200 \mu \mathrm{l})$ were loaded directly onto $1.5 \times 50-\mathrm{cm}$ Sephacryl S-500 columns equilibrated in FSP buffer $120 \mathrm{~mm}$ Tris at $\mathrm{pH} 7.8,0.1 \%$ Triton X-100,60 mM KCl, $2.5 \mathrm{~mm}$ EDTA) (Abmayr et al. 1988; Reed et al. 1988). For affinity purification of splicing complexes, AdML pre-mRNA was prehybridized to a biotinylated $2^{\prime}$-O-methyl oligoribonucleotide complementary to a sequence inserted at the 3' end of exon 2 (gift from A. Lamond), assembled into splicing complexes, fractionated by gel filtration, and bound to avidin-agarose as described (Reed 1990). Bound complexes were then washed four times in $1 \mu l$ of $20 \mathrm{~mm}$ Tris $(\mathrm{pH} 7.8$ ), containing either 150 or $250 \mathrm{mM} \mathrm{NaCl}$. Total RNA was prepared from equivalent amounts of each affinity-purified complex and end-labeled with ${ }^{32} \mathrm{pCp}$ and RNA ligase as described (Reed 1990). Native gel electrophoresis of splicing complexes was carried out as described (Konarska and Sharp 1987), except that $2.5 \mu \mathrm{l}$ of $7.5 \mathrm{mg} / \mathrm{ml}$ heparin was added to $25-\mu \mathrm{l}$ reactions, and $5-10 \mu \mathrm{l}$ of each reaction was fractionated on the gel.

\section{In vitro complementation assays}

Extracts used for in vitro complementation assays (Figs. 4 and 5 ) were prepared by incubating extracts for $10 \mathrm{~min}$ at $30^{\circ} \mathrm{C}$ with different amounts of cold competitor RNA. Initially, we determined the range of competitor concentrations that blocked assembly of naked pre-mRNA into splicing complexes /data not shown). These amounts of competitor were then used for the experiments shown in Figures 4 and 5. Aliquots of the indicated gel-filtration fractions (Fig. 5) or splicing reactions (Fig. 4) were incubated under splicing conditions in $25-\mu \mathrm{l}$ reactions containing $10 \mu \mathrm{l}$ of the competitor-titrated extracts. Complementation reactions were incubated for the times indicated in the figure legends.

\section{Acknowledgments}

We thank Keiko Kumatori and Joy Kingston for excellent technical assistance. We are grateful to Maria Bennett and Tom Maniatis for valuable discussions and comments on the manuscript. We thank Angus Lamond for the 2'-O-methyl oligonucleotide and Magda Konarska for pBSAd10. R.R. is a Lucille P. Markey Scholar. This work was supported by a grant from the Lucille P. Markey Charitable Trust and a grant from the National Institutes of Health.

The publication costs of this article were defrayed in part by payment of page charges. This article must therefore be hereby marked "advertisement" in accordance with 18 USC section 1734 solely to indicate this fact.

\section{References}

Abmayr, S.M., R. Reed, and T. Maniatis. 1988. Identification of 
a functional mammalian spliceosome containing unspliced pre-mRNA. Proc. Natl. Acad. Sci. 85: 7216-7220.

Barabino, S.M.L., B.J. Blencowe, U. Ryder, B.S. Sproat, and A.I. Lamond. 1990. Targeted snRNP depletion reveals an additional role for mammalian UI snRNP in spliceosome assembly. Cell 63: 293-302.

Bindereif, A. and M.R. Green. 1987. An ordered pathway of snRNP binding during mammalian splicing complex assembly. EMBO /. 6: 2415-2424.

1990. Identification and functional analysis of mammalian splicing factors. In Genetic engineering, principles and methods. (ed. J.K. Setlow), pp. 201-225. Plenum Press, New York/London.

Black, D.L., B. Chabot, and J.A. Steitz. 1985. U2 as well as U1 small nuclear ribonucleoproteins are involved in pre-mes senger RNA splicing. Cell 42: 737-750.

Blencowe, B.J., B.S. Sproat, U. Ryder, S. Barabino, and A.I. Lamond. 1989. Antisense probing of the human U4/U6 snRNP with biotinylated 2'-OMe RNA oligonucleotides. Cell 59: 531-539.

Brody, E. and J. Abelson. 1985. The "spliceosome": Yeast premessenger RNA associates with a $40 \mathrm{~S}$ complex in a splicingdependent reaction. Science 228: 963-967.

Brow, D.A. and C. Guthrie. 1989. Splicing a spliceosomal RNA Nature 337: 14-15.

Cheng, S.C. and J. Abelson. 1987. Spliceosome assembly in yeast. Genes \& Dev. 1: 1014-1027.

Frendewey, D. and W. Keller. 1985. Stepwise assembly of a premRNA splicing complex requires U-snRNPs and specific intron sequences. Cell 42: 355-367.

Fu, X.-D. and T. Maniatis. 1990. Factor required for mammalian spliceosome assembly is localized to discrete regions in the nucleus. Nature 343: 437-441.

Ge, H. and J.L. Manley. 1990. A protein factor, ASF, controls cell-specific alternative splicing of SV40 early pre-mRNA in vitro. Cell 62: 25-34.

Grabowski, P.J. and P.A. Sharp. 1986. Affinity chromatography of splicing complexes: U2, U5, and U4 + U6 small nuclear ribonucleoprotein particles in the spliceosome. Science 233: 1294-1299.

Grabowski, P.J., S.R. Seiler, and P.A. Sharp. 1985. A multicomponent complex is involved in the splicing of messenger RNA precursors. Cell 42: 345-353.

Konarska, M.M. and P.A. Sharp. 1986. Electrophoretic separation of complexes involved in the splicing of precursors to mRNAs. Cell 46: 845-855.

- 1987. Interactions between small nuclear ribonucleoprotein particles in formation of spliceosomes. Cell 49: $763-774$

1988. Association of U2, U4, U5, U6 small nuclear ribonucleoproteins in a spliceosome-type complex in the absence of precursor RNA. Proc. Natl. Acad. Sci. 85: 54595462.

Konarska, M.M., R.A. Padgett, and P.A. Sharp. 1984. Recognition of cap structure in splicing in vitro of mRNA precursors. Cell 38: 731-736.

Krainer, A.R. and T. Maniatis. 1985. Multiple factors including the small nuclear ribonucleoproteins $U 1$ and $U 2$ are necessary for pre-mRNA splicing in vitro. Cell 42: 725-736.

- 1988. RNA splicing. In Frontiers in transcription and splicing (ed. B.D. Hames and D.M. Glover), pp. 131-206. IRL Press, Oxford/Washington D.C.

Krainer, A.R., T. Maniatis, B. Ruskin, and M.R. Green. 1984. Normal and mutant human $\beta$-globin pre-mRNAs are faith fully and efficiently spliced in vitro. Cell 36: 993-1005.

Krainer, A.R., G.C. Conway, and D. Kozak. 1990. The essential
pre-mRNA splicing factor SF2 influences 5 '-splice site selection by activating proximal sites. Cell 62: $35-42$.

Kramer, A. 1988. Pre-splicing complex formation requires two proteins and U2 snRNP. Genes \& Dev. 2: 1155-1167.

Kramer, A. and U. Utans. 1991. Three protein factors (SF1, SF3 and U2AF) function in pre-splicing complex formation in addition to snRNPs. EMBO $\%$. 10: 1503-1509.

Lamond, A.I., M.M. Konarska, P.J. Grabowski, and P.A. Sharp. 1988. Spliceosome assembly involves the binding and release of U4 small nuclear ribonucleoprotein. Proc. Natl. Acad. Sci. 85: 411-415.

Lamond, A.I., S.M.L. Barabino, and B.J. Blencowe. 1990. The mammalian pre-mRNA splicing apparatus. In Nucleic acids and molecular biology (ed. F. Eckstein and D.M.J. Lilley), pp 243-257. Springer-Verlag, Berlin/Heidelberg, Germany.

Mattaj, I. W. 1990. Splicing stories and poly(A) tails: An update on RNA processing and transport. Curr. Opin. Cell Biol. 2: 528-538.

Melton, D.A., P.A. Krieg, M.R. Rebagliati, T. Maniatis, K. Zinn, and M.R. Green. 1984. Efficient in vitro synthesis of biologically active RNA and RNA hybridization probes from plasmids containing a bacteriophage SP6 promoter. Nucleic Acids Res. 12: 7035-7056.

Nelson, K.K. and M.R. Green. 1988. Splice site selection and ribonucleoprotein complex assembly during in vitro premRNA splicing. Genes \& Dev. 2: 319-329.

Parker, R., P.G. Siliciano, and C. Guthrie. 1987. Recognition of the TACTAAC box during mRNA splicing in yeast involves base pairing to the U2-like snRNA. Cell 49: 229-239.

Pikielny, C.W., B.C. Rymond, and M. Rosbash. 1986. Electrophoresis of ribonucleoproteins reveals an ordered assembly pathway of yeast splicing complexes. Nature 324: 341-345.

Pruzan, R., H. Furneaux, P. Lassota, G.Y. Hong, and J. Hurwitz. 1990. Assemblage of the prespliceosome complex with separated fractions isolated from Hela cells. I. Biol. Chem. 265: 2804-2813.

Reed, R. 1990. Protein composition of mammalian spliceosomes assembled in vitro. Proc. Natl. Acad. Sci. 87: 80318035 .

Reed, R. and T. Maniatis. 1988. The role of the mammalian branchpoint sequence in pre-mRNA splicing. Genes \& Dev. 2: $1268-1276$

Reed, R., J. Griffith, and T. Maniatis. 1988. Purification and visualization of native spliceosomes. Cell 53: 949-961.

Ruby, S.R. and J. Abelson. 1988. An early hierarchic role of Ul small nuclear ribonucleoprotein in spliceosome assembly. Science 242: 1028-1035.

Seraphin, B. and M. Rosbash. 1989. Identification of functional U1 snRNA-pre-mRNA complexes committed to spliceosome assembly and splicing. Cell 59: 349-358.

- 1991. The yeast branchpoint sequence is not required for the formation of a stable Ul snRNA-pre-mRNA complex and is recognized in the absence of U2 snRNA. EMBO J. 10: 1209-1216.

Seraphin, B., L. Kretzner, and M. Rosbash. 1988. A Ul snRNA : pre-mRNA base pairing interaction is required early in yeast spliceosome assembly but does not uniquely define the 5' cleavage site. EMBO I. 7: 2533-2538.

Siliciano, P.G. and C. Guthrie. 1988. 5'-splice site selection in yeast: Genetic alterations in base-pairing with $U 1$ reveal additional requirements. Genes \& Dev. 2: 1258-1267.

Steitz, J.A., D.L. Black, V. Gerke, K.A. Parker, A. Kramer, D. Frendewey, and W. Keller. 1988. Functions of the abundant U-snRNPs. In Structure and function of major and minor SNURPS (ed. M. Birnsteil) pp. 115-154. Springer-Verlag, Heildelberg, Germany. 
Swanson, M.S. and G. Dreyfuss. 1988. RNA binding specificity of hnRNP proteins: A subset bind to the $3^{\prime}$ end of introns. EMBO I. 7: 3519-3529.

Utans, U. and A. Kramer. 1990. Splicing factor SF4 is dispensable for the assembly of a functional splicing complex and participates in the subsequent steps of the splicing reaction. EMBO J. 9: 4119-4126.

Vijayraghavan, U., M. Company, and J. Abelson. 1989. Isolation and characterization of pre-mRNA splicing mutants of Saccharomyces cerevisiae. Genes \& Dev. 3: 1206-1216.

$\mathrm{Wu}, \mathrm{J}$. and J.L. Manley. 1989. Mammalian pre-mRNA branch site selection by $\mathrm{U} 2$ snRNP involves base pairing. Genes \& Dev. 3: 1553-1561.

Zamore, P.D. and M.R. Green. 1989. Identification, purification, and biochemical characterization of U2 small nuclear ribonucleoprotein auxiliary factor. Proc. Natl. Acad. Sci. 86: $9243-9247$.

1991. Biochemical characterization of U2 snRNP auxiliary factor: An essential pre-mRNA splicing factor with a novel intranuclear distribution. EMBO I. 10: 207-214.

Zhuang, Y. and A.M. Weiner. 1986. A compensatory base change in U1 snRNA suppresses a 5 '-splice site mutation. Cell 46: 827-835.

Zillmann, M., S.D. Rose, and S.M. Berget. 1987. Ul small nuclear ribonucleoproteins are required early during spliceosome assembly. Mol. Cell. Biol. 7: 2877-2883.

Zillmann, M., M.L. Zapp, and S.M. Berget. 1988. Gel electrophoretic isolation of splicing complexes containing U1 small nuclear ribonucleoprotein particles. Mol. Cell. Biol. 8: 814 821. 


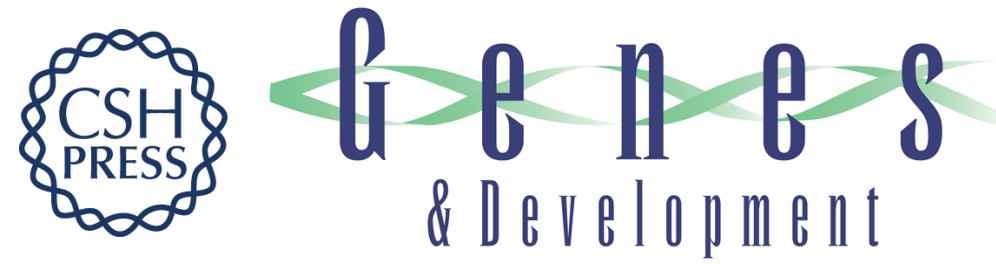

\section{An ATP-independent complex commits pre-mRNA to the mammalian spliceosome assembly pathway.}

$S$ Michaud and R Reed

Genes Dev. 1991, 5:

Access the most recent version at doi:10.1101/gad.5.12b.2534

References This article cites 46 articles, 18 of which can be accessed free at:

http://genesdev.cshlp.org/content/5/12b/2534.full.html\#ref-list-1

License

Email Alerting

Service

Receive free email alerts when new articles cite this article - sign up in the box at the top right corner of the article or click here.

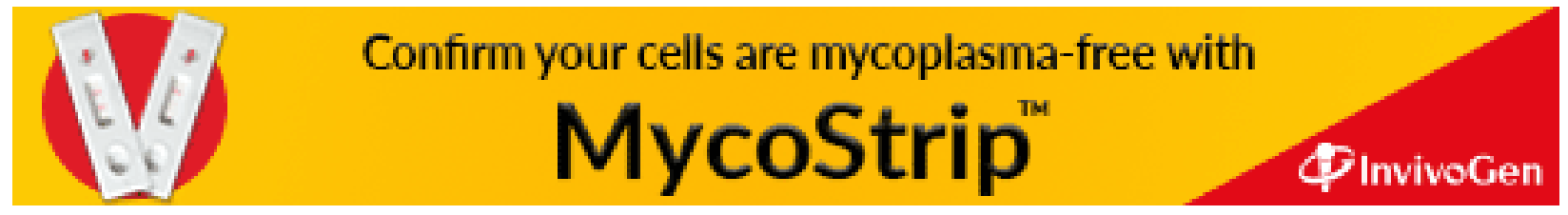

